\title{
The Business of Development in Post-Colonial
} Africa

\section{Lara Petersen}

\section{OpenEdition}

\section{Journals}

Electronic version

URL: https://journals.openedition.org/anthropodev/1633

DOI: 10.4000/anthropodev. 1633

ISSN: 2553-1719

Publisher

Presses universitaires de Louvain

Printed version

Date of publication: 31 December 2021

Number of pages: $225-227$

ISBN: 978-2-39061-188-2

ISSN: 2276-2019

\section{Electronic reference}

Lara Petersen, "The Business of Development in Post-Colonial Africa", Anthropologie \& développement [Online], 52 | 2021, Online since 31 December 2021, connection on 09 December 2022. URL: http:// journals.openedition.org/anthropodev/1633 ; DOI: https://doi.org/10.4000/anthropodev.1633

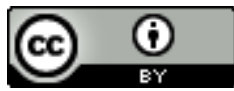

Creative Commons - Attribution 4.0 International - CC BY 4.0

https://creativecommons.org/licenses/by/4.0/ 


\title{
The Business of Development in Post-Colonial Africa
}

\author{
Véronique Dimier and Sarah Stockwell (eds.), 2020, Cambridge, \\ Palgrave Macmillan, $360 \mathrm{p}$.
}

Lara Petersen*

The editors and authors of The Business of Development in Post-Colonial Africa show how firms originating in the former colonial powers have used the business opportunities created by development aid and adopted the narrative of development to protect and enhance their own business after formal decolonisation.

While the narratives and actors of development as well as business in Africa have been studied extensively, little research exists about the common agendas and cooperation in both fields. This gap in scholarship may come as a surprise - after all, the principles of development aid have long held that for every dollar spent, one should be returned (to the donor country's own companies). It is only in recent years that the proportion of so-called tied aid has decreased noticeably (OECD, 2021). Hence, this book is an interesting read as it also helps to understand not only this aspect of African history but also todays actors, power relations and interests in Africa. The authors are well established as well as early career historians. They used public and private archives as well as interviews to collect their information and hence provide input from a wealth of different sources.

For private enterprises from former European colonial powers independence of the African states meant losing their privileged status. What strategies did they adopt to continue doing business in the now potentially hostile environment? How did they respond to the new supranational political institutions such as the European Union or the United Nations? While some of them moved their businesses to other regions this book concentrates on those who saw opportunities and stayed. With a strong focus on the first years after independence, i.e. the 1960 s, the book adds a new perspective to post-colonial studies.

A common aspect of all examples in the book is the fact that African governments pushed for Africanization of the economy, including the banking sector. Nevertheless, despite these efforts they continued to be dependent on the donor institutions, banks,

\footnotetext{
*Johannes-Gutenberg University, Germany; lara.cornelia@gmail.com
} 
and firms of the former colonial powers. While this is not a new insight this book is one of the first to provide empirical examples of how exactly corporations and their supporting European governments protected their interests in the now independent countries. However, African governments were by no means passive pawns of European corporate interests. Instead, many of them were able to use the competition of donor governments and their companies in their own interest, to stay in power and increase their own influence. The wealth made available to the ruling classes fostered large scale corruption to establish their neopatrimonial systems.

The authors of the book cover three major themes. First, post-colonial African governments frequently put development at the top of their agenda. The book outlines how private companies, business associations and the governments of the former colonial powers used the language and rhetoric of development to protect and support their own economic interests. The second theme is how "development as a business" evolved, showcasing the business opportunities that arose for companies from funds made available by development institutions. The third theme concerns the networks between private companies and governments that have been established to protect the interests of these firms. Most of the chapters cover at least two of these three topics. Three essays are portrayed below as examples.

O. Van den Bossche's section in the book is the only one that does not focus on the time after independence. Instead, between 1975 to 2000 the former European Economic Community (EEC) (now EU) signed a series of trade and development treaties with African, Caribbean and Pacific states. Starting with the so-called Lomé agreement from 1975, the essay portrays the influence that European business associations, in particular from the so-called Group of Seven of the largest countries, have exercised over decades on the European Economic Community's negotiations. In the negotiations, these private sector actors underlined the importance of their business for the economic development of the ACP countries. However, O. Van den Bossche criticizes the lobbyists as well as the EEC for claiming to care about development in the ACP states while actually mainly pushing their own agenda.

An example for the second theme is presented by the contribution of S. Stockwell. She describes how British as well as international companies in Africa benefited from the British Colonial Development Corporation's (CDC) change in practices over the decades. The CDC was established in the 1940s to invest into areas considered essential for the development of the colonies but unattractive for private investments. In the early years, the CDC ventured on their own but many of these investments failed. Therefore, the CDC's board started looking for experienced partners and found them in the private sector. During the 1960s, the CDC provided funding and expertise to private companies to exploit opportunities these companies identified in the new African nation's economies. In many cases the CDC absorbed the investing company's financial risks and therefore enabled activities that would have not been undertaken by private companies alone. As a result, the CDC turned from a money losing organisation into a profitable business for the British tax payer. 
A.B. Bamba's chapter is demonstrating an example of the third topic: the networks used by companies from the former colonial power. Utilizing their contacts from colonial times, French companies continued to dominate the economy of Côte d'Ivoire after independence. A.B. Bamba shows how these deeply entrenched structures worked using the example of the Ivorian manufacturing and construction industries. To develop manufacturing the Ivorian government focused on attracting and protecting foreign investments. Additionally, building on their strong pre-existing relationships French research institutions including the Société d'études pour le développement économique et social, the Bureau pour le développement de la production agricole, and the Office de la recherche scientifique et technique d'outre-mer (ORSTOM) were able to write the largescale development plans for the government. By doing so they did not only create business for themselves, but also protected the interest of the French companies executing these plans. In particular, the French construction sector benefited from largescale development projects. Additionally, several French companies were able to win tenders by influencing the way they were designed in the first place so that they had an advantage over their competition. Also, some of them were able to influence the government institutions to award the contracts directly without tendering publicly. These efforts were supplemented by French development finance institutions like the Caisse nationale as well as the Fonds d'investissement pour le développement économique et social (FIDES). Although Ivorian intellectuals openly opposed the French influence, it was only at the end of the 1970s that the calls for economic decolonisation arose again.

Although most of the essays in this book cover the early post-colonial times, the topics covered are still very relevant today. For example, French companies continue to maintain close ties to government officials in their former colonies and still enjoy an advantage over their non-French peers even if their influence has diminished over the years. Also, development is still seen as business opportunity for European companies. Recently, many of them have complained about the Asian competition that is winning a large share of the African countries' tenders. However, with substantial funding provided by China the parallelisms with late colonial and early independence European practices are eye catching.

Reading the book helps understanding African history as well as the history of today's power relations and the use of development narratives in European-African relations.

\section{Bibliography}

Organization for Economic Cooperation and Development (OECD), 2021, "2020 Report on the DAC Recommendation on Untying ODA", 35 p., https://one.oecd.org/document/DCD/DAC(2020)54/ FINAL/en/pdf (accessed 25 May 2021). 